ISSN 2227-7102

www.mdpi.com/journal/education

Article

\title{
An Educational Resource on Water and Health as a Teaching Aid in French Primary Schools-Part II: Design and Validation
}

\section{Chantal Savanovitch * and Marie-Pierre Sauvant-Rochat}

Faculty of Pharmacy, Department of Public Health and Environment, University of Auvergne, EA 4681, PEPRADE, BP 10448, Clermont-Ferrand F-63000, France;

E-Mail: m-pierre.sauvant-rochat@udamail.fr

* Author to whom correspondence should be addressed; E-Mail: chantal.savanovitch@udamail.fr; Tel.: +33-4-7317-8059; Fax: +33-4-7317-7914.

Received: 25 August 2013; in revised form: 21 October 2013 / Accepted: 23 October 2013 /

Published: 1 November 2013

\begin{abstract}
An educational resource on water and health, using an approach focused on health education and environmental health education, was developed to help teachers in the classroom. The implementation of health education programs in French primary schools is explained. Three specific objectives were identified, targeting 3rd, 4th, and 5th year pupils: water as a body constituent, water as a nutrient element, and water as a factor in hygiene, and their individual contribution to good health. The project was led by academics in close collaboration with education and health professionals (school nurses, public health engineers), and people working in health promotion organizations and environmental associations. The method used for the design and validation of the resource was adapted to the educational objective. The "Water and Health" educational resource is structured in 25 modules and includes 89 work files. It was validated in the classroom and includes an assessment of the teaching material and the pupils' results. The resource has been published in French by the Regional Teachers' Resource Centre (CRDP Auvergne, France) and is distributed by the National Teachers' Resource Network (Sceren).
\end{abstract}

Keywords: educational resource; water; health education; environmental health education; children; primary school 


\section{Introduction}

In France, education is a national mandate and the syllabus is the same in all schools [1]. Primary schooling is divided into three cycles: the early learning cycle in nursery school (cycle 1); the basic learning cycle in pre-school, and the 1st and 2nd grades in primary school (cycle 2); and the consolidation cycle in the 3rd, 4th, and 5th grades in primary school (cycle 3) [1]. The national program sets out the knowledge and skills to be acquired at each stage of the syllabus [1]. The main objectives of cycle 3 are to master the French language and the basic elements of mathematics. Classes in history, geography, civic education, modern languages, physical education and sport, and experimental science and technology are provided and contribute to the building of a common knowledge and skills base. The science training focuses on investigative procedures, which develop the curiosity of children, their creativity, their critical faculties and their interest in scientific and technical progress [2]. The aim of this approach is to raise children's awareness of the natural world and to promote a sense of personal responsibility with regard to the environment, the living world, and health.

The French educational system follows the recommendations of the Ottawa Charter in promoting health at school [3]. The objectives of health education are to enable pupils to acquire the skills needed to make free and responsible choices about health, and to create conditions in which all pupils are able to succeed, with particular attention to those who are vulnerable owing to disability, social situation, or health [4]. Being able to read, the ability to look for and to classify information, knowledge about the body and health constitute some examples of skills developed at primary schools that enable pupils to exercise control over their own health [4]. Schools are one of the main places where children build their lives [4]. Although they do not have an effect on all determinants of health (biological determinants, for example), schools have an impact via teaching and the daily life of the school community [4]. Davo-Blanes and La Parra recorded the suggestions of a focus group of Spanish pupils in years three and six of primary school (aged around 8 and 12 years old, respectively) on how to promote their own health [5]. They concluded that schoolchildren should be enabled to take ownership of their health, particularly in relation to the school environment [5]. Health education, as defined in the French education system, involves multiple fields such as nutrition, hygiene, physical activity, and safety on the road. In French schools, health education is not the prerogative of a specific category of teacher but concerns all staff members and also all school stakeholders [4]. A specific feature of French schools is the presence of doctors and nurses working within the educational system [6]. As a result, health education activities at school can be implemented using a multidisciplinary approach that takes into account teacher availability and timetable constraints. In a study of the teaching practices of primary school teachers $(n=626)$ in health education in two French regions and of how they perceived their role, three quarters of the teachers declared that they took part in health education activities [7]. In most cases, however, these activities were related to topics covered in the existing syllabus. Two-thirds worked alone and the others mainly in association with the school health services [7].

Water and health education is now an integral part of the syllabus in France [1]. However, although many initiatives have promoted healthy food and eating habits in the school setting, little has been done to promote water intake. Moreover, the promotion of water includes the concept of environmental health, as defined by the Helsinki declaration on action for environment and health in 
Europe [8]. The protection and treatment of water are necessary to maintain a high quality of water and maintain a healthy population. A review of the literature on the relation between water and health and the implementation of teaching about water and health in primary schools has been presented in a separate work, which also gives the resources available in France on this topic [9].

It seemed of interest, therefore, to develop an educational resource on water and health that would adopt an approach focused on overall health education and environmental health education to be used as supporting material for teachers in the classroom. The present paper describes and discusses the design and validation of this resource, called "Water and Health".

\section{Methods}

The method used for the design and development of the educational resource followed the recommendations published in the reference framework for health education [10,11]. The steps of the development of the resource are described in Scheme 1.

Scheme 1. Design and development of the "Water and Health" educational resource.

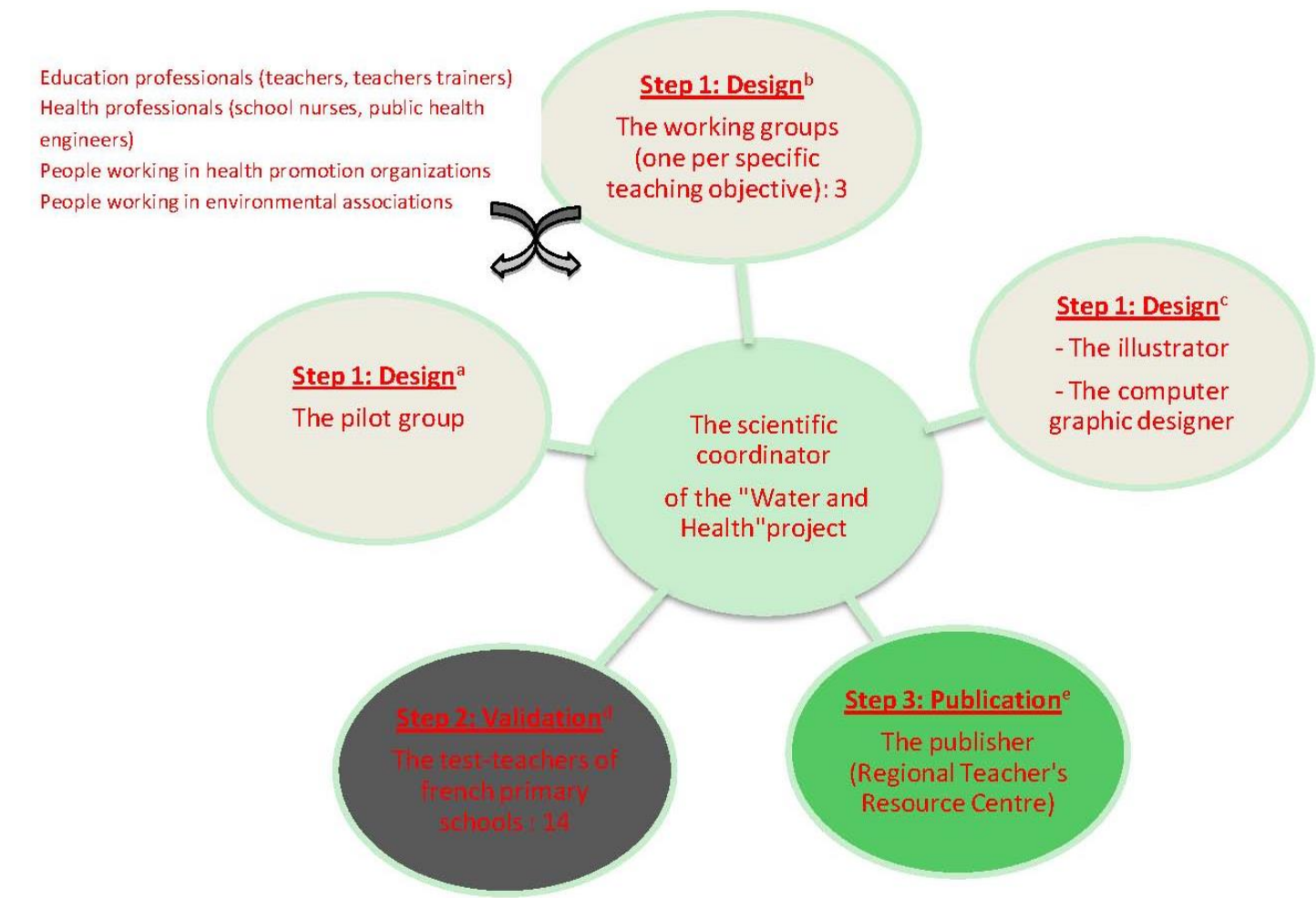

${ }^{a}$ The pilot group: definition and validation of objectives of the « Water and Health » resource (one working session); validation of the content of the training sessions developed by the working groups (three working sessions); ${ }^{\mathrm{b}}$ The three working groups: conception and development of the different training sessions (Group 1: "Water as a body constituent" (eight working sessions); Group 2: "Water as a nutrient element" (eight working sessions); Group 3: "Water as a factor of hygiene" (eight working sessions)); ${ }^{\mathrm{c}}$ The illustrator and the computer graphic designer: providing technical support for each training session developed; ${ }^{d}$ The testteachers of French primary schools: validation of the training sessions developed by the working groups and approved by the pilot group (the teachers tested the resource in classes with the pupils); ${ }^{\mathrm{e}}$ The publisher (Regional Teacher's Resource Centre): publication of the French version of the "Water and health" educational resource (January 2012). 


\subsection{Objective of the "Water and Health" Educational Resource}

The main objective of the "Water and Health" educational resource is to teach schoolchildren (cycle 3) about water and health using an approach focused on overall health and environmental education. Three specific teaching aims were identified and defined as follows (Table 1):

- water as a body constituent, i.e., a fluid essential for life and proper body functioning;

- water as a nutrient element, i.e., the sole necessary drink and a vector of mineral nutrients;

- water as a factor in hygiene, contributing to good health.

Table 1. The objectives of the "Water and Health" educational resource for primary schools.

\begin{tabular}{|l|l|l|}
\hline \multicolumn{2}{|c|}{ GENERAL OBJECTIVE OF THE "WATER AND HEALTH" RESOURCE } \\
\hline \multicolumn{2}{|c|}{ To instruct pupils from 9-11 years old in the relation between water and health } \\
using an approach focused on health education and environmental health education
\end{tabular}




\subsection{Composition of Working Groups (Scheme 1)}

The project was led by academics in close collaboration with education professionals (teachers, teacher trainers), health professionals (school nurses, public health engineers), and people working in health promotion organizations and environmental associations. Three working groups (one per specific teaching objective) were set up and supervised by a pilot group. An illustrator and a computer graphic designer were recruited for technical support. An academic played the role of scientific coordinator and was included in the pilot group and in each working groups to link working sessions.

\subsection{Design of the "Water and Health" Educational Resource}

The "Water and Health" educational resource is structured in modules, divided into three parts, each corresponding to a specific objective (Table 1). At the end of each part, an "Assessment session" evaluates the knowledge potentially acquired by the pupils. Taking into account grade-specific differences, two grade "Assessment sessions" were developed for each theme, one for the 3rd grade and another for the 4th and 5th grades. A chronological order is suggested for the different training sessions according to a structured teaching approach. However, each session can be taught independently of the others (except for the introduction sessions, which have to be done first). Specific support tools relevant to certain sessions were also created, along with interactive exercises. The structure of each training session follows the same pattern:

- A teaching file, indicates the operational objective of the session, gives notes on the teaching approach for the session, adapted if necessary to the grade, useful materials, an approximate estimate of the duration of the session, and a collective summing-up. The teaching approach was designed to enhance the core content of mathematics, sciences and language, while improving knowledge about, and awareness of water and health. For example, the files may include calculations, experiments, and reading texts.

- An activities file, to be completed by the pupils.

- An answers file, with a key for the teacher to pupil activities.

\subsection{Validation of the "Water and Health" Educational Resource}

All the sessions devised by the working groups were validated by the pilot group. Before publication, the resource was submitted for validation to 14 test-teachers in primary classes over a period of six months. Teachers were recruited by the Regional Education Adviser from the Regional Education Authority. All volunteered to test the resource in class. Three of the teachers had previously taken part in the working groups but the 11 others had not seen the resource before. Some teachers taught classes at different levels and others had mixed-level groups (four teachers had 4th and 5th grades in the same class, and one had 3rd and 4th grades together). They were invited to a one-day seminar to present the resource. They were given the kit free to carry out training sessions with their pupils. It was required from the teachers to test the resource to perform in class at least all the sessions of one same part or more parts (the resource was made of three parts). The aims of this trial were to establish how teachable the materials were, how well they were adapted to the pupils' level, whether they produced observable results in the acquisition of knowledge and skills, and whether the approach 
was appreciated by teachers and pupils alike. The teachers completed assessment forms to evaluate these different points and returned them to the scientific coordinator. The assessment grid was specifically developed for validation. It includes the following information: the title of the training session, the class grade, the link to the session with the syllabus, the achievement of objective(s) of the session, the time required for the teaching of session, the timeline in between session, the feasibility of the session, the acquisition of knowledge and skills, the modification(s) and/or improvement(s) required on the teaching file and/or the activities file and/or the answers file and/or support tools, and suggestion(s). After the test period, two days of brain-storming were organized by the scientific coordinator with the test-teachers to validate their suggestions for corrections and/or modifications to improve the quality of the teaching material.

\subsection{Evaluation of the "Water and Health" Educational Resource}

An assessment of the teaching material and results is included in this project and will be analysed after publication of the resource.

- For assessment of the material: a self-administered questionnaire is included in the teaching kit for teachers to assess the material. It must be completed after use of the resource in class and returned to the scientific coordinator, who will oversee assessment. The quality of the resource will be judged on the basis of criteria published in the reference table of the National Institute for Health Prevention and Education (INPES) [12].

- For assessment of the results: the "Assessment sessions" must be completed by pupils before and after the corresponding modules. They assess results in terms of knowledge acquisition. The scores of each pupil are recorded anonymously in a table, which is returned by the teacher to the scientific coordinator. The scores obtained before and after the modules are compared to evaluate a potential gain in points. In addition, overall pupil satisfaction is assessed on a Smiley scale.

\section{Results}

\subsection{Design and Contents of the "Water and Health" Educational Resource}

The design and development of the "Water and Health" resource was carried out by the three working groups over 24 working sessions and validated by the pilot group in four sessions between September 2007 and September 2008 (Scheme 1).

The final version of the "Water and Health" educational resource is composed of a teacher's booklet comprising 25 modules (25 "Teaching files" and six "Assessment sessions") [13]. The booklet comes with a CD-Rom that includes 29 activity files and a corresponding key, seven support tools and four interactive exercises [13]. The resource is divided into a "General Introduction", three thematic parts and a "General Conclusion", as described below [13]. 


\subsection{1. "General Introduction" Session}

The "General Introduction" presents the three themes and the four cartoon characters, specifically created to accompany the sessions.

\subsubsection{First Part: "Water as a Body Constituent"}

The specific objective of this part is to make pupils aware that water is an indispensable fluid for life and proper body functioning. Six sessions are dedicated to the interpretation of thirst and the hydration status of the body.

\section{Session I.1: "Introduction"}

The introduction session uses pictures illustrating the theme of water to elicit pupils' ideas and impressions.

\section{Session I.2: "Thirst"}

This session aims to promote good hydration status with the aid of a comic strip specifically created for the resource as a teaching support tool. It provides elements that enable pupils to quickly recognize the sensation of thirst. The pupils are taught the effects on health of mild and severe dehydration, as defined by loss of body weight caused by fluid loss. The main manifestations associated with thirst are explained, starting with the first signs of dehydration such as dryness of the mouth, headache, irritability, tiredness, difficulties in mental concentration, chronic constipation, darker urine, and finishing with increase in body temperature [14].

Sessions I.3-I.6: "The hydration status of the body"

The notions of body water content, body water balance and functions, and the identification of specific situations requiring increased fluid intake are successively described over four sessions:

- Session I.3 "Body water content": Humans need water to survive because water is the most abundant component of the body. Total body water (TBW) is about $60 \%$ of body mass: an average $70 \mathrm{~kg}$ male has a TBW content of about 42 litres [15]. An interactive exercise on the CD-Rom shows the respective water content of certain organs and tissues.

- Session I.4 "Body water balance": This is calculated by the difference between the sum of water intake (from beverages and food) and endogenous water production and the sum of water loss (from urine, faeces, exhaled air, and sweat). Special attention is drawn to the fact that water balance is achieved when water loss is compensated for by water intake and metabolic water production. A debate is organized to highlight specific situations such as fever, diarrhoea and high temperatures that can modify body water balance. Thirst and hunger, coupled with free access to food and fluids, to offset water loss act together to regulate body water balance on a day-to-day basis.

- Session I.5 "The main functions of body water": The aim of this session is to discover the main role of water in the human body using index cards specifically created for the resource. The 
index cards illustrate that water contributes to molecule transport via the bloodstream, to numerous biochemical reactions in the body and to the body's process of temperature regulation.

- Session I.6 "Specific situations": Through a classroom debate, this session highlights the main situations in which water intake needs to be increased. Water intake and loss vary widely among individuals and even within the same person according to physical activity level, environmental conditions (climate), diet, and illness.

To conclude, the key message delivered by the teacher is the importance of drinking regularly throughout the day without waiting to become thirsty, and especially in situations that increase fluid requirements such as physical activity, fever, and diarrhoea.

\subsubsection{Second Part: "Water as a Nutrient Element"}

The specific objective of this part is to show pupils that water is the only essential drink we need and that it is a vector of mineral nutrients. Seven sessions explain the basic concepts of mineral salts, and the relation between water and diet.

Sessions II.1-II.5: "Introduction to mineral salts"

Five sessions provide basic knowledge of what mineral salts are. In the introduction session, children are invited to taste various bottled waters with contrasting mineral composition to discover the different tastes that water can have (session II.1). The taste varies depending on the concentration of the common dissolved minerals: calcium, magnesium, potassium, and sodium, in combination with chloride, sulphate, and carbonate. The type and nature of minerals in water reflect the geological strata that the water flows through. The children are then asked to imagine and perform experiments that reveal the presence of mineral salts in water. Detailed experiments such as evaporation (session II.2) and dissolution (session II.3) are organized. Thirdly, the pupils are invited to comment on information given on the labels of bottled water (session II.4). A proper understanding of these elements is essential to become an informed water consumer. Finally, the main minerals and their functions are presented using mineral identity cards specifically created for the resource (session II.5).

The message is that water contains mineral salts that are very important for our health, such as calcium, which is required for healthy teeth, bones, and muscles.

\section{Sessions II.6-II.7: "Water and diet"}

Pupils are given a $24 \mathrm{~h}$ recall card that is filled in at home to record fluid intake (session II.6), according to the reference method [16]. In the classroom, fluid intake is discussed in quantitative and qualitative terms with regard to French recommendations [17]. Session II.7 presents the water content of certain food products. Food water content is usually below $40 \%$ in bakery products, between $40 \%$ and $70 \%$ in cooked meals, $>80 \%$ in fruits and vegetables, and about $90 \%$ in milk [15]. Special attention is given to the contribution of these food items to maintaining optimal hydration status.

To conclude, the key message delivered by the teacher is that, to ensure prolonged good health, water should constitute the main daily fluid intake and, in particular, that it should be preferred to 
sweetened beverages. Pupils are reminded that tap water in France is of high sanitary quality and are encouraged to make it part of their daily intake.

\subsubsection{Third Part: "Water as a Factor in Hygiene"}

The specific objective of this section is to show pupils that water is an essential factor in hygiene and that it contributes to good health. This is done over 10 sessions that explain the basic concepts of microorganisms and deal with the topics of personal and domestic hygiene, the water cycle and water treatments.

\section{Sessions III.1-III.3: "Introduction to microorganisms"}

The aim of the introduction is to find out what the pupils know or think about water, hygiene and health (session III.1). Pupils are taught that microorganisms are present everywhere around us but that they are not all harmful and some are even useful. French legislation does not allow microorganisms to be cultured in primary schools and so the pupils are shown photographs of an experiment, which demonstrates that microorganisms can be found on both clean and dirty hands. The pupils then take part in a card game specifically created for the resource that enables them to recreate the successive steps of the experiment (session III.2). Session III.3 explores the different ways in which microorganisms are transmitted. The pupils imagine situations in which they simulate coughing, sneezing, and transmission via contact. These activities form the basis for a discussion about personal hygiene.

Sessions III.4-III.6: "Personal and domestic hygiene"

The first session targets personal hygiene: hand washing with soap and water, bathing, brushing of teeth, and washing of clothes (session III.4). Pupils look at the hygiene rules they must observe when they go to the swimming pool, an activity that is included in the French primary school program (session III.5). Session III.6 looks at domestic hygiene practices, with a special emphasis on hygiene in the bedroom and food handling and food storage.

Sessions III.7-III.10: "Water cycle and water treatments"

Wastewater is contaminated with substances such as human waste, food scraps, oils, soaps and chemicals. In the home, wastewater includes water from sinks, showers, bathtubs, toilets, washing machines, and dishwashers. Session III.7 gives examples of the water cycle at home (water supply and wastewater). In session III.8, the pupils carry out an experiment in which they treat wastewater. They learn that water must be treated before it is released back into the environment, in a way that allows sustainable development. They also learn that treatment plants reduce pollutants in wastewater to a level that poses no danger to the environment. Session III.9 explores water treatment before and after use, and the last session (III.10) looks at the water cycle in nature.

The key take-home messages are the vital need to respect good hygiene practices and the importance of water treatment for the protection of the environment. 


\subsection{5. "General Conclusion" Session}

The "General Conclusion" session rounds off the resource activities and recapitulates the main key points for the children.

\subsection{Validation of the "Water and Health" Pedagogic Resource}

For validation before publication, the "Water and Health" resource was tested by 14 primary school test-teachers in class. Each session of a same part has been tested in 3rd and 4th and/or 5th grade. The test-teachers filled in an assessment grid for each session completed with their pupils and returned it to the scientific coordinator for compilation. All suggestions of test-teachers were discussed during brainstorming sessions and collective decisions were adopted. A suggestion, the implementation of the experiment of the culture of microorganisms (session III.2), because French legislation forbids it for hygiene reasons, was not taken into account although the pedagogical interest. Improvement and modifications were implemented for pedagogical reasons and feasibility. They focused on:

- simplification of the training sessions, which were considered too complex,

○ by dividing training sessions into two (session II.6, session III.4, session III.8);

$\circ$ by splitting existing activity files into two (session III.4, session III.7) or adding a new activity file (session III.8, general introduction session, general conclusion session).

- Revising the teaching time required for the sessions, often underestimated (session III.1, session III.3-4, session III.10).

- The addition of some useful clarifications and a glossary. Scientific documentation, specifically developed for "Water and Health" resource was proposed to help non-specialists teachers. Lack of time was an issue and suggestion to replace it with a glossary was adopted. Glossary is now included.

- Modification of the order for third part sessions: the session on water cycle in nature (session III.10) was moved to the end of the part (after validation) instead of first place (prior to validation), whereas the session on water cycle at home (session III.7) was placed first (after validation).

- The assessment presentation reformat on two pages instead of one, easing the reading. The assessment forms were doubled, two instead of one, the first one for the 3rd grade and the second for 4 th and 5 th grade.

- The deletion of a specific space for the summing-up in the answers file to allow more space for the activities. The teachers have considered that conclusion could be written in pupil's notebooks.

- Introduction of numbering of different files (teaching files, activities files and answers files). Chronological order was proposed before validation without numbering, each session can be taught independently (except introduction session). The teachers suggest including numbering, due to the size of files.

This process took place between October 2008 and June 2009. The educational content and design of the resource were finalized during 2010. 


\subsection{Publication of the "Water and Health" Educational Resource}

In 2011, steps were taken to find a publisher. In January 2012, the resource was published by the Regional Teachers' Resource Centre (CRDP Auvergne, France). The French version of the resource is distributed by the National Teachers' Resource Network (Sceren network) [13]. About 400 resources have been sold to the teachers since the publication.

\section{Discussion}

The project described in this paper places great emphasis on the beneficial effects of water drinking on health. A novel approach was used in the design and contents of the resource, which was validated first by a pilot group and secondly by test-teachers. It incorporates an assessment of the teaching material and pupils' results. The strengths and the limitations of the "Water and Health" resource project are discussed below.

\subsection{Strengths of the "Water and Health" Resource Project}

\subsubsection{Originality of the Partnership}

The project involved professionals working in curricular and extracurricular settings. This type of partnership, which to our knowledge is uncommon, between all stakeholders (university and primary school teachers, other education professionals, health professionals, and environmental engineers) around a common theme (water and health) should be encouraged. The collaborative venture was appreciated by all taking part, and in particular by the teachers, who were able express their constraints and needs.

\subsubsection{Suitable for Non-Specialists in Water and Health Education}

Johnston-Molloy et al. conducted a survey, using semi-structured interviews, of 12 primary school teachers in the Midlands of Ireland to assess their knowledge of all issues related to water [18]. They reported that the participants had a poor knowledge of hydration requirements and the associated beneficial effects on mental concentration [18]. Their results cannot be extrapolated to other school environments since the study involved few participants and was conducted in a foreign country. In France, teachers specialize in the discipline of their choice such as life and earth sciences, history-geography, and literature during their teacher-training course. Except for life and earth science specialists, water and health education is a little known subject for French teachers, as for those in other countries. In light of this, the "Water and Health" resource can be considered as a manageable tool for non-specialists to be used by all teachers irrespective of their initial specialization.

\subsubsection{Accompaniment of Teachers Beginning Work with the Resource}

The final version of the resource includes 89 files in the booklet or on the CD-Rom. A training session (half a day) would be useful for teachers only recently acquainted with the resource. The publisher offers this possibility and the session is led by the scientific coordinator. 


\subsection{Limitations of the "Water and Health" Resource Project}

\subsubsection{Limitations Related to the Approach Usually Adopted in Health Education}

Although three main areas were identified in the health education project (acquisition of knowledge and skills, life skills, and development of resistance to pressure from the immediate environment) the resource deals only with the first two [4]. All the stakeholders were involved in the design of the resource but the children took part only in the validation of the project and not in the initial phases.

\subsubsection{Limitations Related to Publishing Constraints}

It was difficult to find a compromise between publishing constraints and educational aims while at the same time maintaining a low purchase price for teachers ( 23 euros). This was the longest phase in the project. Only the computer graphic designer and the illustrator, recruited specifically for the development of the resource, receive copyright payments. The Regional Teacher's Resource Centre (CRDP) proposed the best compromise between the educational aims and the optimal cost. However, negotiations were needed with the CRDP. For example, the format of the resource chosen by the teachers was a workbook (including all the files and the support tools) but the cost was too high. After negotiations, a compromise was reached, i.e., a booklet and a CD-Rom. The booklet included the teaching files and a visual recall of the other files (the activity files, the answers files and the specific support tools), which were included in a CD-Rom.

\subsubsection{Limitations Related to the School Environment}

For the authors, the main aims were to promote water intake and good hygiene practices at school. Regarding restoration in schools, drinking water is barely approached in the French nutritional recommendations and the regulations. The French nutritional guidelines recommend drinking water, as a daily intake (instead of other drinks at schools) and installation of chilled drinking fountains is recommended [19,20]. Further, drinking water must be available without restriction in schools [21]. The importance of hydration of school pupils, and water promotion in primary schools in relation with the problem of overweight/obesity, have been previously reported [9]. However, there is a major drawback to promoting water intake at school in France since water availability and access are often limited to the toilet facilities. Children often say that they encounter problems with school toilets, which can be unhygienic or poorly maintained. This has an impact on their use and some children go as far as never using them during the school day [22]. Hence, as water is often available only in the toilets children do not have an adequate fluid intake during the school day. In addition, the avoidance of toilet use can have implications for the children's health, such as constipation and urinary tract disease. The good hygiene practices and the relationship with the survey of the quality of drinking water in France have been previously reported [9]. In a systematic review of the literature on the effects of water and sanitation in schools, Jasper et al. have highlighted the impacts of water and sanitation inadequacies in the academic environment. Many schools in developing and developed countries lack adequate water and sanitation services, with associated potential detrimental effects on health and school attendance [23]. These authors provide evidence for an increase in water intake with 
increased provision of water and increased access to water facilities. Moreover, they reported a decreased diarrheal and gastrointestinal diseases with increased access to adequate sanitation facilities in schools. Regarding the recommendations in France, it is essential that schools have sufficient and properly equipped for washing and drying hands sanitation to respect the good hygiene practices [19]. In 2007, a report by the National Observatory of Security and Accessibility of Educational Institutions focused on sanitation inadequacies in elementary schools and its relationship with health and wellbeing [24]. Bidet et al. highlighted that the approach of hygiene in schools needs to be taken account from the design of schools to the maintenance of sanitation facilities and need the contribution of all people involved in the design, the maintenance and the education [25]. A coherent environment needs to be created before water health can be properly promoted at school. If this is achieved, the "Water and Health" resource could be used as an effective educational support for teachers in the classroom. Additional studies that examine the relationship between drinking water and sanitation facilities in schools are needed to characterize the impact on health, well-being, and educational achievements.

\section{Conclusions}

The end goal of any educational tool should be to satisfy a real demand for its future users. This principle guided the design of the "Water and Health" resource, which was developed in multidisciplinary working groups that took fully into account the teachers' wishes. In addition, the project complies with French policy on Public Health, Nutritional Public Health and Environmental Health by focusing on health education and environmental health education [26,27].

\section{Acknowledgments}

We would like to thank everybody who took part in the project, including Christine Archimbaud (Faculty of Pharmacy, Clermont-Ferrand, France) for help in performing the microbiological experiments and photography, and Stephanie Tubert (Faculty of Dentistry, Clermont-Ferrand, France) for reading of the note on oral hygiene. Special thanks go to the working group for pertinent discussions during the design and validation of the resource.

\section{Members of the French working group:}

Nadine AMBLARD, Technical Medical Advisor, Cabinet du Recteur, Clermont-Ferrand

Jean-Claude AULAGNIER, Teacher, Ecole élémentaire Jean Jaurès, Clermont-Ferrand

Jeanine BATISSE, Technical Nurse Advisor, Inspection Académique 63

Sylvie BERTHIAUD, Teacher, Ecole élémentaire Léon Dhermain, Cournon

Dominique BIGAY, School Inspector, Inspection Académique 63

Monique BONNAFOUS, Technical Nurse Advisor, Cabinet du Recteur, Clermont-Ferrand

Stéphanie BOURLETIAS, Teacher, Ecole élémentaire, Ménétrol

Eric CHAMPION, Teacher, Ecole élémentaire Les Jacquemarts, Aigueperse

Françoise CHASLES, Health Studies Officer, Agence Régionale de Santé d'Auvergne

Françoise CHAUX, Teacher, Ecole élémentaire La Fleurie, Lempdes

Blandine CORONT-DUCLUZEAU, Regional Education Authority Project Leader, Cabinet du Recteur, Clermont-Ferrand 
Brigitte DEFRADAS, Teacher, Ecole Paul Bert, Clermont-Ferrand

Daphné DUPREZ, Project Leader, Association $\mathrm{H}_{2} \mathrm{O}$

Floripe FAURE, School Nurse, Lycée Professionnel Roger Claustres, Clermont-Ferrand

Pascal FERRET, Teacher, Ecole élémentaire, Châteaugay

Anne-Marie GUILLAUMIN, Regional Education Adviser, Inspection Académique 63

Dominique GUILLOT, Regional Education Adviser, Inspection Académique 63

Nelly GRUET, Teacher, Ecole élémentaire Henri Bournel, Cournon

Christophe JAURAND, Project Manager, Instance Régionale d'Education et de Promotion de la Santé Auvergne

Sylvie JUILHARD, Teacher, Ecole élémentaire Henri Bournel, Cournon

Philippe LEOTOING, School Inspector, Adjoint à l'Inspecteur d'Académie, Inspection Académique 63

Catherine LHERMIE, School Nurse, Collège Molière, Beaumont

Claudine MARTIN, Teacher, Ecole des Sciences, Centre Main à la Pâte, Châteauneuf-Les-Bains

Armelle MATHIEU-HERMET, Health Studies Officer, Agence Régionale de Santé d'Auvergne

Laurence MITCHELL, Teacher, Ecole élémentaire Paul Bert, Clermont-Ferrand

Catherine MOREAU, Teacher, Ecole élémentaire, Châteaugay

Didier MULNET, Teacher Trainer, Institut Universitaire de Formation des Maîtres d'Auvergne, Université Blaise Pascal Joëlle PERBET, Teacher Trainer, Institut Universitaire de Formation des Maîtres d'Auvergne, Université Blaise Pascal

Sylviane ROUX, Teacher, Ecole élémentaire Beaudonnat, Aubière

Christelle SALAMON, Teacher, Ecole élémentaire Les Jacquemarts, Aigueperse

Odette SEPCHAT-PAPON, School Nurse, Collège Treimonteix, Clermont-Ferrand

Catherine SOL, Teacher, Ecole élémentaire, Châteaugay

Elvire VAN STAEVEL, Anthropologist, Institut Universitaire de Formation des Maîtres d'Auvergne, Université Blaise Pascal

This work was supported by the Public Health Regional Group of Auvergne (France) (grant number P74 (2007), grant number R24 (2008)).

\section{Conflicts of Interest}

The authors declare no conflict of interest.

\section{References}

1. Educational Ministry. French Curriculum: Kindergarten and Primary School, BOEN. 2008. Available online: http://www.lfs.edu.sg/fr/enseignement/cbilingues/formulaires/french_ curriculum.pdf (accessed on 28 October 2013).

2. La Main A la Pâte. Enseigner les sciences à l'école (in French). Available online: http://lamap.fr. (accessed on 28 October 2013)

3. World Health Organization. The Ottawa Charter for Health Promotion (First International Conference on Health Promotion), Ottawa 1986. Available online: http://www.who.int/ healthpromotion/conferences/previous/ottawa/en/ (accessed on 28 October 2013)

4. Jourdan, D. Health Education in Schools: the Challenge of Teacher Training; Institut National de Prévention et d'Education pour la Santé: Saint-Denis, France, 2011. 
5. Davó-Blanes, M.C.; La Parra, D. Children as agents of their own health: Exploratory analysis of child discourse in Spain. Health Promot Int. 2012, 4, 1-11.

6. Pommier, J.; Jourdan, D.; Berger, D.; Vandorne, C.; Piorecka, B; de Carvalho G.S. School health promotion: organization of services and roles of health professionals in seven European countries. Eur. J. Public Health 2009, 20, 182-188.

7. Jourdan, D.; Pommier, J.; Quidu, F. Practices and representations of health education among primary school teachers. Scand. J. Public Health 2010, 38, 86-94.

8. World Health Organization. Helsinki Declaration on Action for Environment and Health in Europe (Second European Conference on Environment and Health. Helsinki), Finland, 1994. Available online: http://whqlibdoc.who.int/euro/1994-97/EUR_ICP_CEH_212.pdf (accessed on 28 October 2013).

9. Savanovitch, C.; Sauvant-Rochat, M.P. An educational resource based on water and health as a teaching aid in French primary schools. Part I: Identification of needs and content. Educ. Sci. 2013, 3, 300-313.

10. Frerotte, M.; Spiece, C.; Grignard, S.; Vandoorne, C. Guide méthodologique: comment créer un outil pédagogique en santé (in French); Bernard De Baecker: Bruxelles, Belgium, 2004.

11. Broussouloux, S.; Houzelle-Marchal, N. Education à la santé en milieu scolaire: choisir, élaborer et développer un projet (in French); Institut National de Prévention et d'Education pour la Santé: Saint-Denis, France, 2006.

12. Lemonnier, F.; Bottero, J.; Vincent, I.; Ferron, C. Outils d'intervention en éducation pour la santé: critères de qualité. Institut National de Prévention et d'Education pour la Santé: Saint-Denis, France, 2005 (in French). Available online: http://www.inpes.sante.fr/CFESBases/catalogue /pdf/883.pdf (accessed on 28 October 2013).

13. Savanovitch, C.; Sauvant-Rochat, M.P. Eau et santé. Outils pour les cycles CE2 CM1 CM2 (in French). SCEREN-CRDP Auvergne: Clermont-Ferrand, France, 2011. Available online: http://www.sceren.com/cyber-librairie-cndp.aspx?l=eau-et-sante\&prod=567778 (accessed on 28 October 2013).

14. Popkin, B.M.; D’Anci, K.E.; Rosenberg, I.H. Water, hydration, and health. Nutr. Rev. 2010, 68, 439-458.

15. European Food Safety Authority. Scientific opinion on dietary reference values for water. EFSA J. 2010, 8, 1459.

16. Muckelbauer, R.; Libuda, L.; Kersting, M. Relative validity of a self-completion $24 \mathrm{~h}$ recall questionnaire to assess beverage consumption among schoolchildren aged 7 to 9 years. Public Health Nutr. 2010, 13, 187-195.

17. Health Ministry. French National Nutrition and Health Program 2011-2015. France, 2010. Available online: http://www.sante.gouv.fr/IMG/pdf/French_National_Nutrition_and_Health_ Program_2011-2015.pdf (accessed on 28 October 2013).

18. Johnston Molloy, C.; Gandy, J.; Cunningham, C.; Slattery, G. An exploration of factors that influence the regular consumption of water by Irish primary school. J. Hum. Nutr. Diet. 2008, 21, 512-515. 
19. Circulaire 2001-118 du 25 juin 2001, relative à la composition des repas et à la sécurité des aliments (in French). BOEN 2001, 9. Available online: http://www.education.gouv.fr/bo/2001/ special9/note.htm (accessed on 28 October 2013).

20. Circulaire 2003-210 du 1er décembre 2003 relative à la santé des élèves dans le cadre du programme quinquennal de prévention et d'éducation (in French). BOEN 2003, 46. Available online: http://www.education.gouv.fr/bo/2003/46/MENE0302706C.htm (accessed on 28 October 2013).

21. Ministère de l'agriculture, de l'alimentation, de la pêche, de la ruralité et de l'aménagement du territoire. Arrêté du 30 septembre 2011 relatif à la qualité nutritionnelle des repas servis dans le cadre de la restauration scolaire (in French). JORF 2011. Available online: http://www.legifrance.gouv.fr/affichTexte.do?cidTexte=JORFTEXT000024614716\&dateTexte= \&categorieLien=id (accessed on 28 October 2013).

22. Barnes, P.M.; Maddocks, A. Standards in school toilet: A questionnaire survey. J. Pub. Health Med. 2002, 24, 85-87.

23. Jasper, C.; Le, T.T.; Bartram, J. Water and sanitation in schools: a systematic review of the health and educational outcomes. Int. J. Environ. Res. Public Health 2012, 9, 2772-2787.

24. Observatoire national de la sécurité et de l'accessibilité des établissements d'enseignement. Les sanitaires dans les écoles élémentaires (in French). Report 2007. Available online: $\mathrm{ftp} / / /$ trf.education.gouv.fr/pub/edutel/syst/ons/sanitaires.pdf (accessed on 28 October 2013).

25. Bidet, G.; Van Staëvel, E.G.; Jourdan, D.; Peymaud, C.; Quinet, M.H. Amélioration de l'hygiène en milieu scolaire (in French). Report 2008. Available online: http://www.afpssu.com/wpcontent/uploads/2013/07/hygiene_en_milieu_scolaire_clermont.pdf (accessed on 28 October 2013).

26. Health Ministry. French National Nutrition and Health Program 2011-2015. France, 2010. Available online: http://www.sante.gouv.fr/IMG/pdf/French_National_Nutrition_and_Health_ Program_2011-2015.pdf (accessed on 28 October 2013).

27. Ministry of Ecology, Energy, Sustainable Development and the Sea; Ministry of Health and Sports; Ministry of Superior Education and Research; Ministry of Labour Relations, Solidarity and Urban Affairs. The second French National Environment and Health Action Plan (NEHAP 2). France, 2010. Available online: http://www.sante.gouv.fr/IMG/pdf/presangl.pdf (accessed on 28 October 2013).

(C) 2013 by the authors; licensee MDPI, Basel, Switzerland. This article is an open access article distributed under the terms and conditions of the Creative Commons Attribution license (http://creativecommons.org/licenses/by/3.0/). 